\title{
Internal and external North Atlantic Sector variability in the Kiel Climate Model
}

\author{
Mojib LatiF*, Wonsun Park, Hui Ding and Noel S. Keenlyside
}

\author{
Leibniz-Institut für Meereswissenschaften, Kiel, Germany
}

(Manuscript received October 31, 2008; in revised form March 19, 2009; accepted April 4, 2009)

\begin{abstract}
The internal and external North Atlantic Sector variability is investigated by means of a multimillennial control run and forced experiments with the Kiel Climate Model (KCM). The internal variability is studied by analyzing the control run. The externally forced variability is investigated in a run with periodic millennial solar forcing and in greenhouse warming experiments with enhanced carbon dioxide concentrations. The surface air temperature (SAT) averaged over the Northern Hemisphere simulated in the control run displays enhanced variability relative to the red background at decadal, centennial, and millennial timescales. Special emphasis is given to the variability of the Meridional Overturning Circulation (MOC). The MOC plays an important role in the generation of internal climate modes. Furthermore, the MOC provides a strong negative feedback on the Northern Hemisphere SAT in both the solar and greenhouse warming experiments, thereby moderating the direct effects of the external forcing in the North Atlantic. The implications of the results for decadal predictability are discussed.
\end{abstract}

\begin{abstract}
Zusammenfassung
Die interne und externe Variabilität im nordatlantischen Raum wurde mit Hilfe einer Kontrollsimulation und angetriebenen Experimenten mit dem Kiel Climate Model (KCM) untersucht. Die interne Variabilität wird anhand der Kontrollintegration analysiert, die externe Variabilität in Integrationen mit periodischem solarem Antrieb und in Treibhausgas-Experimenten mit erhöhter Kohlendioxidkonzentration. Die nordhemisphärische Oberflächenlufttemperatur zeigt in der Kontrollsimulation starke, über den roten Hintergrund herausragende, Variabilität auf Zeitskalen von Dekaden, Jahrhunderten und Jahrtausenden. Besondere Aufmerksamkeit gilt der Meridionalen Umwälzbewegung (MOC). Sie spielt eine wichtige Rolle hinsichtlich der Generierung interner Klimamoden. Darüber hinaus wirkt die MOC sowohl in den Experimenten mit solarem als auch mit Treibhausgas-Antrieb als eine negative Rückkopplung für die nordhemisphärische Oberflächenlufttemperatur, wodurch der Einfluss des direkten Antriebs im Bereich des Nordatlantiks abgeschwächt wird. Die Bedeutung der Ergebnisse für die dekadische Vorhersagbarkeit wird diskutiert.
\end{abstract}

\section{Introduction}

Climate variability can be either generated internally by interactions within or between the individual climate subcomponents (e. g., atmosphere, ocean, and sea ice) or externally by e. g. volcanic eruptions, variations in the solar insolation at the top of the atmosphere, or changed atmospheric greenhouse gas concentrations in response to anthropogenic emissions. Examples of internal variations are the El Niño/Southern Oscillation (ENSO), the Pacific Decadal Variability (PDV), the North Atlantic Oscillation (NAO), or the Atlantic Multidecadal Variability (AMV). The existence of the internal variability can readily explain not only the redness of typical climate spectra but also some of the peaks superimposed on them. The general stochastic climate model concept (HASSELMANN, 1976) is a suitable zero-order model of these features.

Externally driven climate variability can result, for instance, from variations in the Earth's orbital parameters which are the pacemakers of the ice age cycles on

\footnotetext{
${ }^{*}$ Corresponding author: Mojib Latif, Ozeanzirkulation und Klimadynamik - Maritime Meteorologie - Leibniz-Institut für Meereswissenschaften, Duesternbrooker Weg 20, 24105 Kiel, e-mail: mlatif@ifm-geomar.de
}

timescales of many millennia (HAYs et al., 1976). On shorter timescales of decades to a few millennia, internal solar physics causes variations of the solar output. The climate record of the Holocene can only be understood when taking into account these variations in solar input to the Earth (CROWLEY, 2000; JANSEN et al., 2007). BOND et al. (2001) describe a solar forcing mechanism which may underlie at least the Holocene segment of the North Atlantic's quasi-periodic 1500-year cycle. Ice records from Greenland also show fluctuations on a similar timescale during the last glacial period: strong warm phases referred to as "Dangaard-Oeschger events" occurred on average around every 1500 years. It is unclear whether Dansgaard-Oeschger events are externally or internally driven, but the similarity in the periodicity to that described by BOND et al. (2001) suggests some external origin. This is supported by GANOPOLSKI and RAHMSTORF (2001) who argue based on simulations with a climate model of intermediate complexity that Dansgaard-Oeschger events are triggered by a weak millennial-scale solar forcing which excites an internal millennial mode of the climate system. However, MUSCHELER and BEER (2006) do not find evidence for this hypothesis in Greenland isotope records. Finally, climate reconstructions of the last two millennia also 

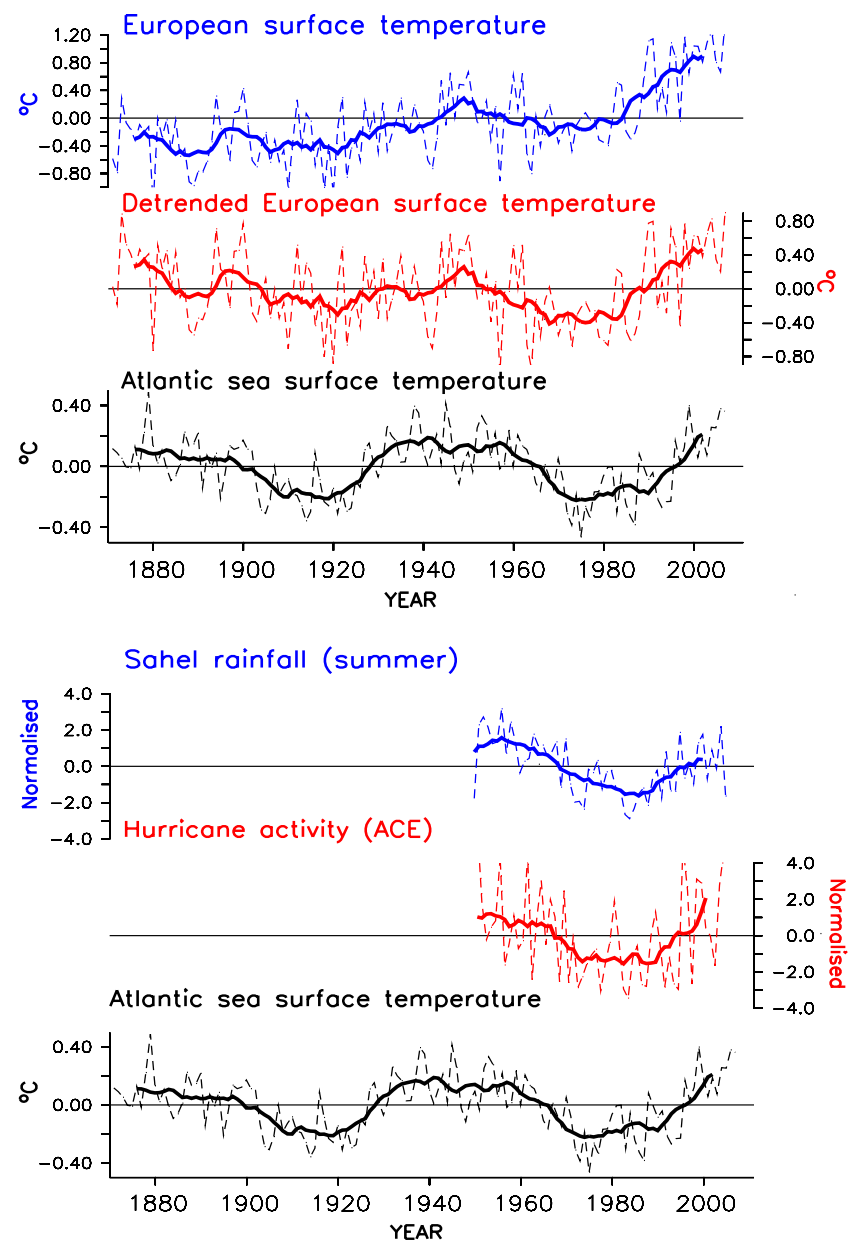

Figure 1: From top to bottom: Annual mean European SAT $\left(5^{\circ} \mathrm{W}-\right.$ $\left.10^{\circ} \mathrm{E}, 35-60^{\circ} \mathrm{N}\right)$, linearly de-trended annual mean European SAT, linearly de-trended North Atlantic SST $\left(0-60^{\circ} \mathrm{N}\right)$, summer Sahel rainfall, Atlantic hurricane activity (ACE index), and North Atlantic SST repeated from above. All time series are deviations from the long-term mean. All temperature time series are in units of $\left[{ }^{\circ} \mathrm{C}\right]$. The Sahel rainfall and the ACE index were normalized with the longterm standard deviation.

suggest a millennial solar forcing. The Medieval Warm Period around 1000-1200 and the Little Ice Age around 1500-1700 were presumably driven at least partly by variations in solar radiation (e. g., CROWLEY, 2000). However, it is still uncertain how widespread and coherent these fluctuations were, so that we cannot confidently attribute them to solar (i.e. a global) forcing. The latter attained a maximum during the Middle Ages, a broad minimum around the middle of the last millennium and high values again during the $20^{\text {th }}$ century. Anthropogenic climate change such as global warming as a result of an enhanced greenhouse effect in response to increased greenhouse gas concentrations is also considered as externally driven.

Here we consider both the internal and external variability as simulated in a series of numerical experiments with the Kiel Climate Model (KCM). Special attention is given to the Meridional Overturning Circulation (MOC) (see e.g., SchmitTner et al., 2005 for review). Since the observational database is insufficient to describe the low-frequency MOC variability, long control integrations of climate models have been used to obtain insight into the dynamics of MOC variability (e.g. DELWORTH et al., 1993; TIMMERMANN et al., 1998; DELWORTH and MANN, 2000; LATIF et al., 2004; KNIGHT et al., 2005 and KNIGHT et al., 2006). Such models simulate MOC variability on a wide range of timescales, from monthly to centennial. LATIF et al. (2004) showed a rather strong connection between indices of MOC and North Atlantic SST in a multicentury control integration of a climate model. This was followed up by LATIF at al. (2006) who reconstructed the relative MOC changes during the $20^{\text {th }}$ century with observed Atlantic sea surface temperature (SST). They used the inter-hemispheric SST dipole, a pattern with opposite polarities in the North and South Atlantic (e.g. FollaND et al., 1986), as a fingerprint of MOC change and report strong multidecadal variability with an increase in MOC strength from the 1970s to the 1990s. This, although supported by forced ocean model simulations (LATIF et al., 2007), can of course be considered only as a very crude estimate of the multidecadal MOC variability.

The strong multidecadal or even longer-timescale variability, internally or externally driven, may mask anthropogenic climate signals which evolve on similar timescales. LATIF et al. (2006), for instance, concluded that the expected anthropogenic weakening of the MOC may not be detectable during the next decades due to the presence of the strong internal multidecadal variability. This may not only apply to the MOC itself but also to other potentially related quantities such as European surface air temperature (SAT), Sahel rainfall or Atlantic hurricane activity (Fig. 1) which are also characterized by pronounced multidecadal variability (e. g., ZHANG and DELWORTH, 2006) and may hinder early detection of an anthropogenic signal. In this study, we investigate the results from integrations with KCM in order to explore the level of internal Northern Hemisphere SAT and MOC variability up to millennial timescales and to investigate the model's response to external (solar and greenhouse gas) forcing. The paper is organized as follows. We describe in section 2 the model and the experimental setups. The internal variability is presented in section 3 , the external variability in section 4 . The implications for decadal predictability are discussed in section 5 . The paper is concluded with a brief summary and a discussion of the main findings in section 6 .

\section{Model and experiments}

The Kiel Climate Model (KCM) described in detail by PARK et al. (2009) consists of the ECHAM5 (ROECKNER et al., 2003) atmosphere general circulation model and the NEMO (MADEC, 2008) ocean-sea ice general circulation model, coupled with the OASIS3 coupler (VALCKE, 2006). No form of flux correction or anomaly coupling is used. The atmospheric resolution is $\mathrm{T} 31\left(3.75^{\circ} \times 3.75^{\circ}\right)$ horizontally with 19 vertical levels. 
(a) Northern Hemisphere Temperature anomalies, annual values Integration with the Kiel Climate Model

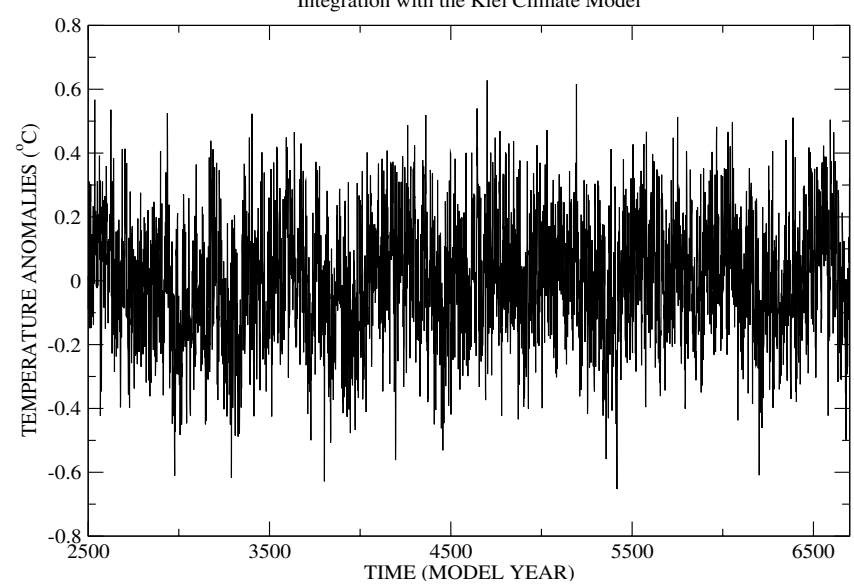

(b) Northern Hemisphere Temperature spectrum, annual values Integration with the Kiel Climate Model

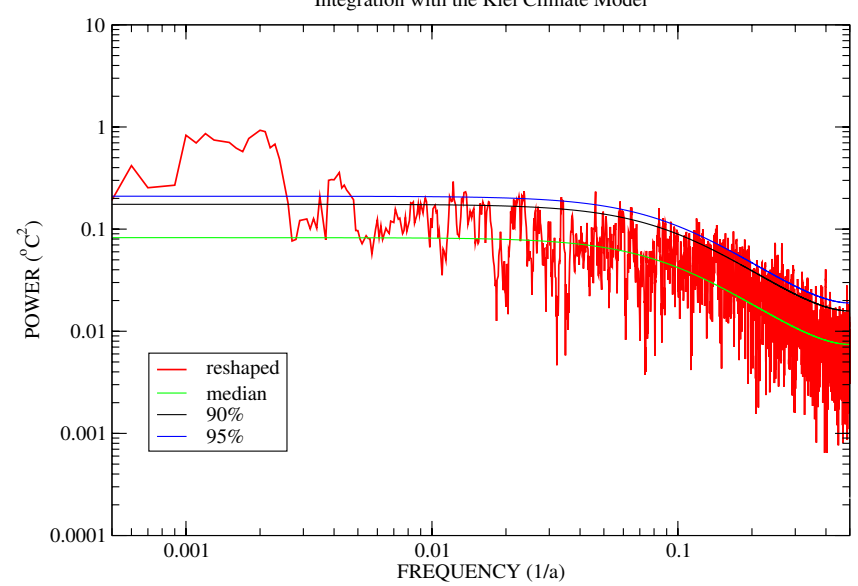

Figure 2: a) Timeseries of annual anomalies of the Northern Hemisphere SAT $\left[{ }^{\circ} \mathrm{C}\right]$ simulated in the control run with the Kiel Climate Model. b) Spectrum $\left[{ }^{\circ} \mathrm{C}^{2}\right]$ of simulated Northern Hemisphere SAT anomalies were computed relative to the long-term mean. The time series was linearly de-trended before calculating the spectrum.

The horizontal ocean resolution is based on a $2^{\circ}$ Mercator mesh and is on average $1.3^{\circ}$, with enhanced meridional resolution of $0.5^{\circ}$ in the equatorial region, and with 31 levels in the vertical.

The internal variability is investigated with a multimillennial control run. KCM was integrated for 5000 years in total using the same model version described in PARK et al. (2009) but with slightly different parameters. We consider here only the last 4200 years after skipping the initial 800 years to account for model spin up. It should be mentioned that the orbital parameters vary slowly according to the Milankovitch Cycles in the control run, as predicted for the next millennia. This, however, should not have a strong influence on the results described below. PARK and LATIF (2008) described the internal MOC variability simulated in the control run. The solar constant $\left(1365 \mathrm{~W} / \mathrm{m}^{2}\right)$ was varied sinusoidal by $\pm 2 \mathrm{~W} / \mathrm{m}^{2}$ with a period of 1000 years in the second experiment. This run is referred to as solar forcing experiment. Four complete cycles were computed. In or- (a) Mean Atlantic Streamfunction

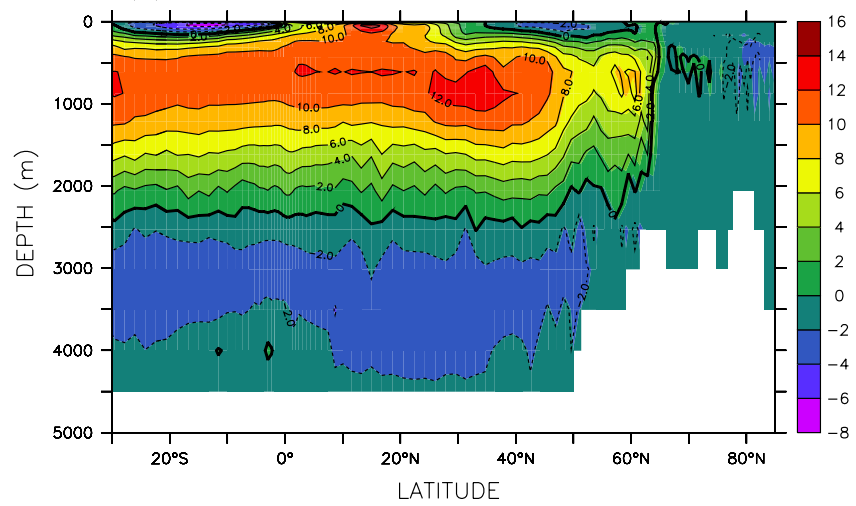

(b) Maximum MOC strength at $30^{\circ} \mathrm{N}$ Atlantic

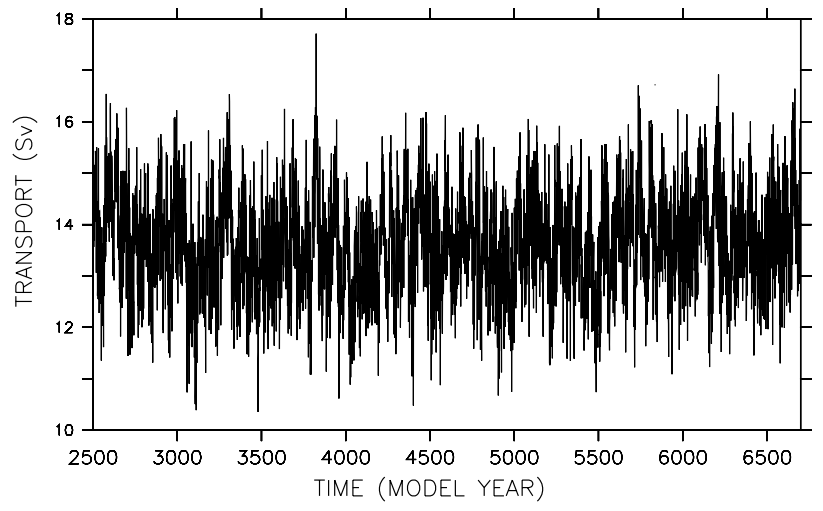

(c) Maximum MOC strength spectrum, annual values

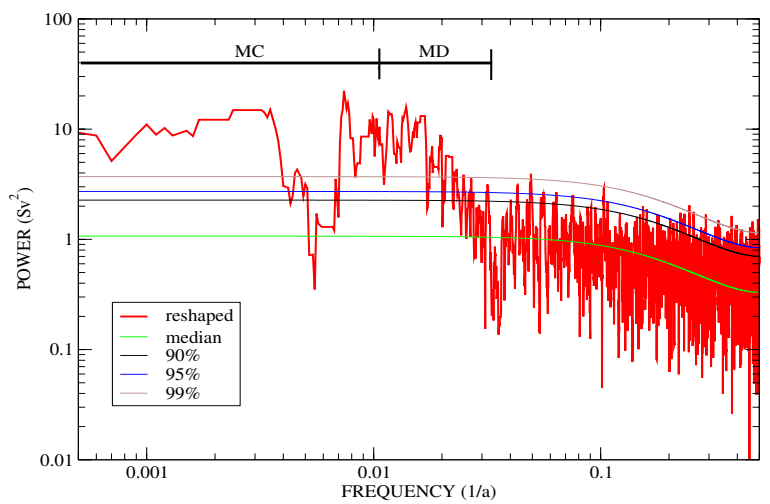

Figure 3: a) Mean MOC [Sv] averaged over all 4200 years, b) time series of MOC strength [Sv] defined as the maximum of the stream function at $30^{\circ} \mathrm{N}$ based on annual averages ( $\left.\sigma=1.02 \mathrm{~Sv}\right)$, and c) power spectrum of the MOC strength $\left[\mathrm{Sv}^{2}\right]$ as function of frequency [1/a]. The multicentennial (MC) and multidecadal bands (MD) are denoted by horizontal lines.

der to study the role of ocean dynamics in the response to solar forcing an additional experiment was performed, in which the dynamical ocean model was replaced by a constant-depth $(50 \mathrm{~m})$ mixed layer ocean model. Only one complete cycle was computed. The investigation of the longer run with KCM revealed that the large-scale response patterns do not change much from cycle to cycle so that we can assume that just one cycle is sufficient. 
(a) Multicentennial composite

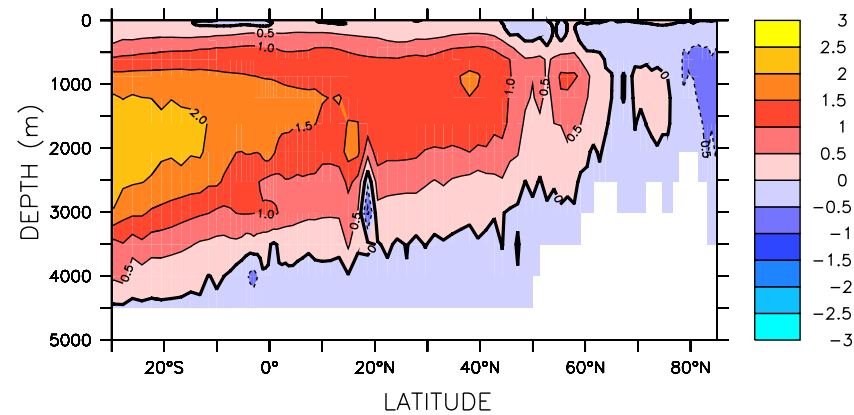

(b) Multidecadal composite

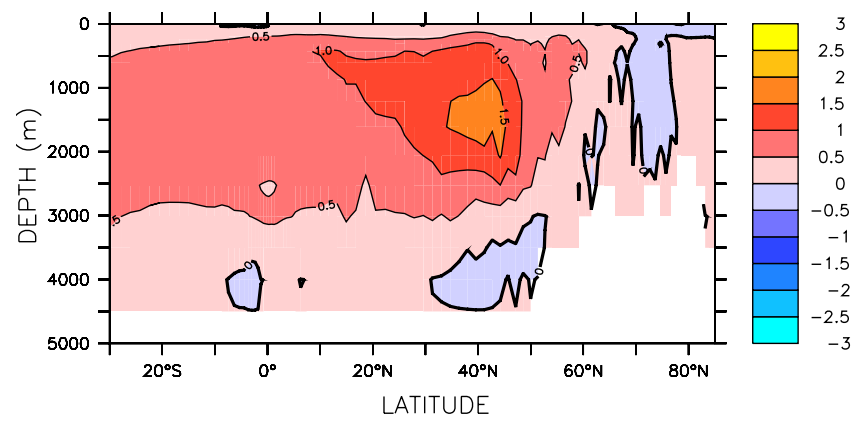

Figure 4: MOC (high minus low) composite [Sv] for strong phases of a) multicentennial and b) multidecadal MOC variability. Composites were computed applying a one-standard deviation criterion. All time series were linearly de-trended prior to the analysis.

We investigate the model response under "present-day" conditions, with a $\mathrm{CO}_{2}$ concentration of $348 \mathrm{ppm}$ that was also used in the control run. The solar forcing experiments should be considered as sensitivity experiments to better understand the climate response to direct solar forcing. The $\mathrm{CO}_{2}$ concentration is increased by $1 \%$ (compound) in an ensemble of four 100 year long greenhouse warming experiments, in which the concentration doubles after about 70 years and is stabilized thereafter for another 30 years.

\section{Internal variability}

Figure 2 displays the evolution of SAT averaged over the Northern Hemisphere simulated in the control run together with the corresponding spectrum. Surprisingly, the level of decadal to centennial variability in Northern Hemisphere surface air temperature (SAT) simulated by $\mathrm{KCM}$ is consistent with that obtained from the JONES and MANN (2004) reconstruction (Table 1). Statistically significant peaks above the $90 \%$ level (relative to the spectrum of a fitted AR1-process) are found at three periods: $\sim 60-90$ years, $\sim 300-400$ years and $\sim 800-1000$ years. The multidecadal peak, however, is quite modest. An interesting result of the control run is the strong level of multicentennial to millennial variability simulated under (almost) constant boundary conditions. We focus in the following on the Atlantic MOC. The mean MOC as described by the overturning streamfunction is simulated reasonably well (Fig. 3a) and consistent with that simulated by other climate models. We computed first an index of the MOC strength as the maximum of the overturning streamfunction at $30^{\circ} \mathrm{N}$. The annual index (Fig. 3b) has a mean value of $13.6 \mathrm{~Sv}$ and exhibits rich variability on different timescales. MOC strength varies between about 11-18 Sv, and decadal to centennial variability is obvious with strong year-to-year fluctuations superimposed. The corresponding spectrum (Fig. 3c) is red up to millennial timescales. At decadal timescales, a broad and statistically significant (above the $99 \%$ level) peak (relative to the spectrum of a fitted AR1-process) is seen at periods of about 50-100 years. Thus, KCM's multidecadal AMV-type MOC variability seems to be oscillatory in nature. It should be mentioned, however, that the model's AMV is centred at periods of about 60 80 years and that the related SAT variability at a period of about 100 years has a different spatial structure, indicating it is governed by different dynamics.

Since we are interested here only in the long-term MOC variability, we averaged the annual data to 5-year means in the subsequent analyses. In order to separate the multidecadal from the multicentennial variability we employ temporal filtering: first, a low-pass filter retaining variability with periods longer than 90 years is applied to investigate multicentennial variability, and second, a band-pass filter, retaining variability with periods between 30 and 90 years to study multidecadal variability. The two filtered time series (not shown) are equivalent to those in PARK and LATIF (2008) except for the 200 year longer time period analyzed here. The corresponding standard deviations are: 1) annual MOC index $=1.02 \mathrm{~Sv}, 2$ ) band-pass filtered (multidecadal) in$\operatorname{dex}=0.46 \mathrm{~Sv}$, and 3) low-pass filtered (multicentennial) index $=0.45 \mathrm{~Sv}$. Composites for the overturning streamfunction were computed using the two filtered time series, applying a one standard deviation threshold. The high minus low composite for the multicentennial variability (Fig. 4a) yields an intensified North Atlantic Deep Water (NADW) cell that extends to deeper levels. The strongest change is simulated at $30^{\circ} \mathrm{S}$, suggesting that the multicentennial MOC variability is driven in the Southern Hemisphere. The composite for the multidecadal variability shows a similar strengthening of the NADW cell (Fig. 4b). The maximum change, however, is simulated near $40^{\circ} \mathrm{N}$ suggesting a northern control of the multidecadal variability, as in many other models.

The SAT pattern associated with the multicentennial and multidecadal variability was computed by linear regression upon the corresponding filtered MOC time series. Again 5-year means were used. The SAT regression patterns (Figs. 5a, b) support the picture that the multicentennial variability is driven in the Southern Hemisphere, while multidecadal variability originates in the Northern Hemisphere. The multicentennial SAT pattern (Fig. 5a) has strongest loadings in the South Atlantic, with maximum changes of $2^{\circ} \mathrm{C} / \mathrm{Sv}$. Explained variances relative to the 5-year means are typically in the range of $10-20 \%$ in this region. The North Atlantic is mostly covered by weaker positive anomalies extending to about $60^{\circ} \mathrm{N}$ (please note the non-linear scale). Explained variances in the North Atlantic, however, are generally low, with the exception of the region $40^{\circ}$ $50^{\circ} \mathrm{N}$. The SAT pattern associated with the multidecadal 
(a) Multicentennial SAT regression

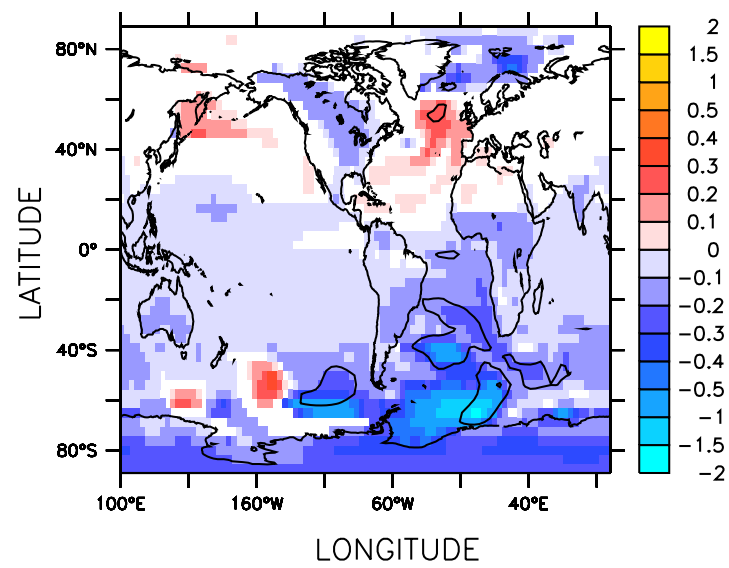

(b) Multidecadal SAT regression

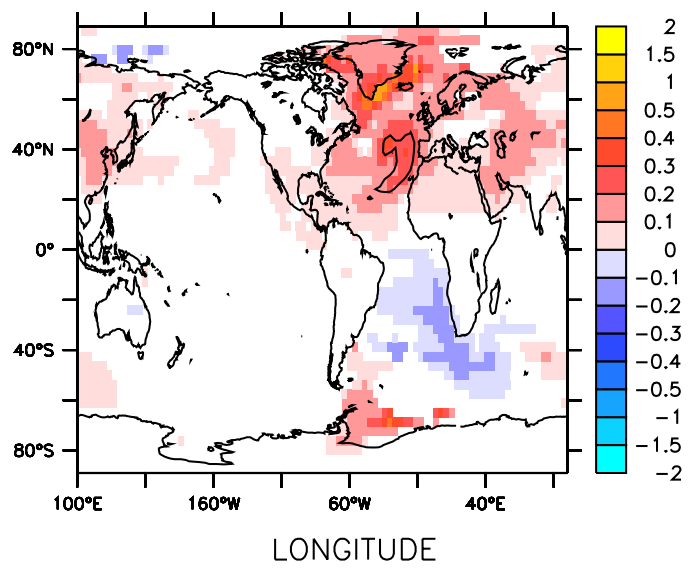

Figure 5: Maps of linear regression coefficients for SAT [K/Sv] upon a) the low-pass filtered MOC strength highlighting the multicentennial variability and b) the band-pass filtered MOC strength highlighting the multidecadal variability. Shading denotes the regression values, contours explained variances (contour interval amounts to 0.1). All time series were linearly de-trended prior to the analysis.

Table 1: Standard deviations computed for 10-year and 100-year means of the Northern Hemisphere surface air temperature (NH-SAT) and Meridional Overturning Circulation (MOC) for control and solar forcing experiments. Reconstructed NHSAT data for the period 200-1899 were taken from JONES and MANN (2004). The latter dataset was obtained from http://www.ncdc.noaa.gov/paleo/pubs/jones2004/jones2004.html.

\begin{tabular}{llllllll}
\hline \multirow{2}{*}{ Standard deviation } & \multicolumn{3}{c}{ NH-SAT } & & \multicolumn{2}{c}{ MOC } \\
\cline { 2 - 3 } \cline { 7 - 8 } & JONES and & ctrl & solar & & ctrl & solar \\
\hline 10yr means & 0.089 & 0.111 & 0.233 & & 0.66 & 0.86 \\
100yr means & 0.068 & 0.061 & 0.212 & & 0.34 & 0.51 \\
\hline
\end{tabular}

variability is clearly dominated by SAT anomalies in the North Atlantic (Fig. 5b). In comparison with the multicentennial pattern, the North Atlantic anomalies are much stronger relative to those in the South Atlantic and they extend farther north into the Arctic. Explained variances are rather small and generally well below $10 \%$, except in a region extending from the Iberian Peninsula into the Tropics. We also investigated the impact of MOC variability on sea ice (not shown). The multicentennial MOC variability is connected to strong changes in Southern Hemisphere sea ice extent. During phases of strong multicentennial events maximum sea ice extent changes from about 15 to almost $20 \cdot 10^{6} \mathrm{~km}^{2}$, a change of $25 \%$. Such a strong internal fluctuation is much larger than the observed increase in Antarctic sea ice extent since the late $1970 \mathrm{~s}$ of about $0.1-0.2 \cdot 10^{6} \mathrm{~km}^{2}$. The Northern Hemisphere sea ice extent does not display any strong centennial-timescale variability. In contrast, sea ice fraction anomalies associated with the multidecadal MOC variability yield coherent changes in the Northern Hemisphere of up to $20 \% / \mathrm{Sv}$, but are not coherent in the Southern Hemisphere. In summary, pronounced internal multidecadal and multicentennial SAT and MOC variability is simulated by KCM in the control run. Furthermore, a clear timescale separation exists in the spatial structures associated with multidecadal and multicentennial MOC variability. KCM even simulates strong internal variability at millennial timescales. How- ever, the control is too short to investigate the millennial variability in a meaningful manner.

\section{External variability}

Northern Hemisphere SAT variability is much stronger in the solar forcing experiment than in the control run (Table 1, Figure 6) and clearly varies approximately in phase with the solar forcing, as indicated by the corresponding cross correlations amounting to more than 0.8 for both decadal and centennial means (Table 2). The decadal standard deviation in the solar forcing experiment is twice as large as that simulated in the control run and the centennial standard deviation is three times as large. Consequently, the variability in the former is also much stronger than that obtained from the JONES and MANN (2004) reconstruction (Table 1). JANSEN et al. (2007), however, report a rather large spread between the different Northern Hemisphere SAT reconstructions. The decadal to centennial variability in the solar forcing experiment ranges at the upper limit of the reconstructions given in JANSEN et al. (2007). European $\left(10^{\circ} \mathrm{W}-\right.$ $\left.30^{\circ} \mathrm{E}, 40^{\circ}-60^{\circ} \mathrm{N}\right)$ and Arctic $\left(60^{\circ}-90^{\circ} \mathrm{N}\right)$ SAT (Figs. 6c, d) also exhibit a clear forced response that can be readily detected without further statistical analyses. The Arctic response is clearly stronger than the European one, which suggests that different feedbacks operate in the two regions. 

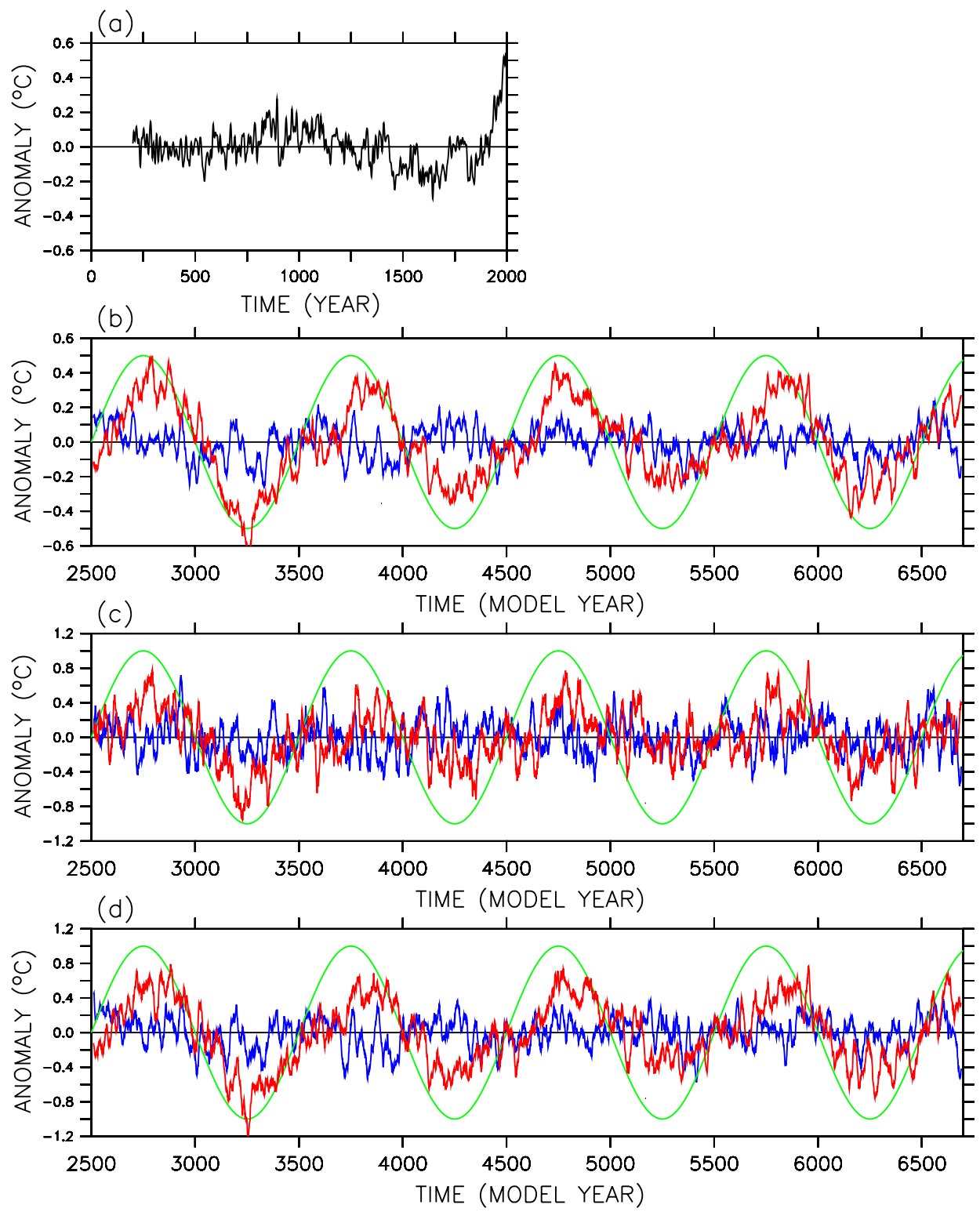

Figure 6: a) Northern Hemisphere SAT anomalies reconstruction from JONES and MANN (2004), b) Northern Hemisphere SAT anomalies simulated in the solar forcing experiment and the control integration, c) European SAT $\left(10^{\circ} \mathrm{W}-30^{\circ} \mathrm{E}, 40^{\circ}-60^{\circ} \mathrm{N}\right)$ from the two experiments, and d) Arctic SAT anomalies $\left(60^{\circ}-90^{\circ} \mathrm{N}\right)$. Blue (red) lines indicate the control (solar forcing) experiment. A 21 -year running mean filter was applied to the model time series. Units are ${ }^{\circ} \mathrm{C}$. All time series were linearly de-trended. The green curves show the phase of the solar forcing.

Table 2: Cross correlations between 10-year and 100-year means of selected time series computed from the control and solar forcing experiments.

\begin{tabular}{|c|c|c|c|c|}
\hline \multirow[b]{2}{*}{ Correlation } & \multicolumn{2}{|c|}{ 10yr means } & \multicolumn{2}{|c|}{ 100yr means } \\
\hline & ctrl & solar & ctrl & solar \\
\hline $\mathrm{MOC}-\mathrm{NH}-\mathrm{SAT}$ & 0.11 & -0.27 & 0.10 & -0.58 \\
\hline Solar constant - MOC & - & -0.41 & - & -0.67 \\
\hline Solar constant - NH-SAT & - & 0.82 & - & 0.89 \\
\hline
\end{tabular}


(a) Maximum MOC at $30^{\circ} \mathrm{N}$ Atlantic, ctrl

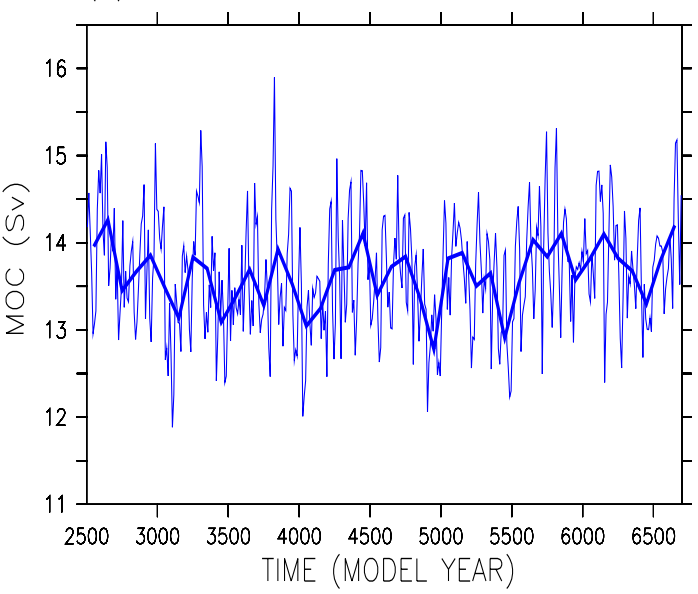

(c) MOC spectrum, 10yr mean values, ctrl

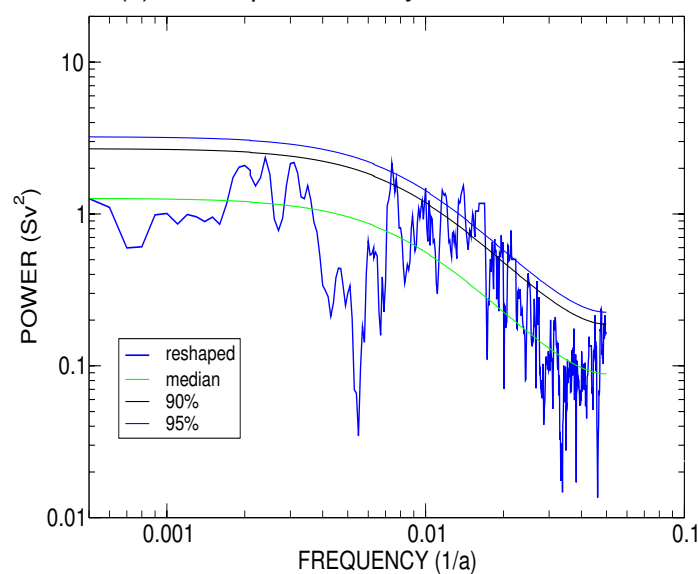

(b) Maximum MOC at $30^{\circ} \mathrm{N}$ Atlantic, solf

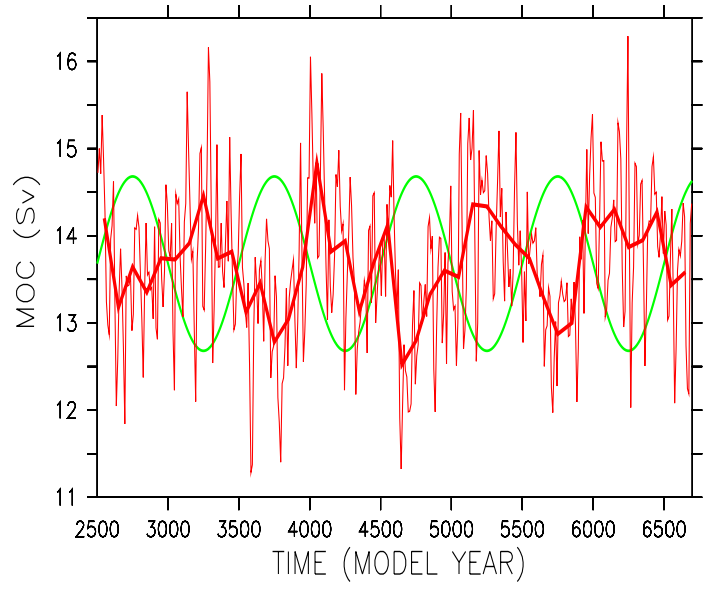

(d) MOC spectrum, 10yr mean values, solf

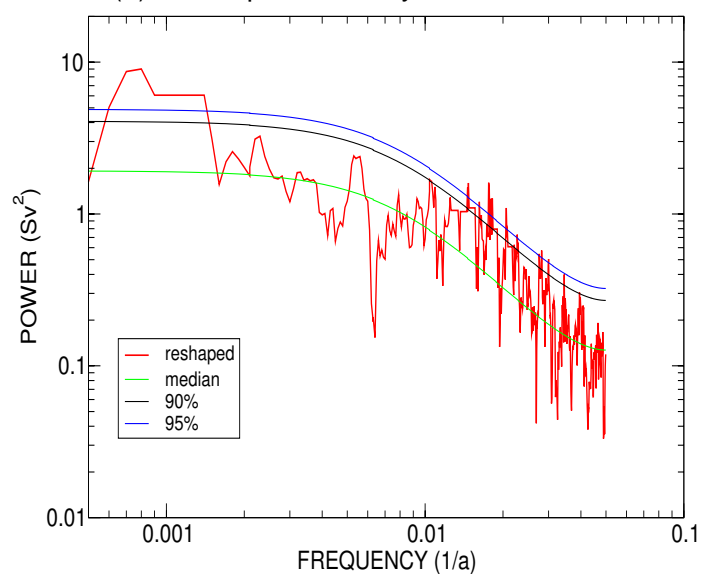

Figure 7: Timeseries of 10-year (thin lines) and 100-year (thick lines) means of MOC strength [Sv] at $30^{\circ} \mathrm{N}$ (as defined as the maximum of the overturning streamfunction) simulated in the a) control integration and b) solar forcing experiment. The green line in $b$ ) shows the evolution of the solar constant to ease comparison. Power spectra $\left[\mathrm{Sv}^{2}\right]$ based on 10 -year mean MOC time series from the c) control and d) solar forcing experiments.

The MOC strongly responds to the solar forcing in KCM (Fig. 7). An MOC response was also found by CUBASCH and Voss (2000) in one of their climate model experiments with different solar forcing reconstructions for the last centuries. The lag between the solar forcing and the MOC is small and of the order of a decade. The MOC variability (Figs. 7a, b) is strongly constrained by the forcing frequency, as seen in the corresponding spectra (Figs. 7c, d). The decadal standard deviation increases by about $20 \%$ compared to that simulated in the control run (Fig. 7a) and the centennial standard deviation by about $50 \%$. The forced MOC response has a strong impact on SAT. A high-MOC minus low-MOC SAT composite was computed using 100-year periods centred on the four maxima and minima in the solar forcing and introducing a lag of 50 years to account for the inertia (Fig. 8a). As expected, most regions exhibit warming. In the North Atlantic, however, the response consists of cooling. Cross correlations between the solar forcing and the MOC changes amount to -0.41 and -0.67 for decadal and centennial means, respectively. Cross correlations were also computed between the changes in MOC and Northern Hemisphere SAT (Table 2). In the control run, the correlations are positive but weak on both decadal and centennial timescales. The sign of the correlation changes in the solar forcing experiment, indicating the MOC acts as a strong negative feedback not only locally in the North Atlantic but also for Northern Hemisphere SAT. In the North Atlantic, the MOC response even overrides the effect of the direct forcing in this region. LUTERBACHER et al. (2004), for instance, show indeed strongest changes over Eastern Europe and little or no cooling in Western Europe in their reconstructions of European temperatures during the Little Ice Age. This finding is consistent with the negative MOC feedback described here, but other processes such as a persistent change in the atmospheric circulation have also to be considered in this context.

In order to separate more clearly the influence of the ocean dynamics, specifically that of the MOC, from at- 
(a) SAT 50yr lag response $\left({ }^{\circ} \mathrm{C}\right), \mathrm{KCM}$

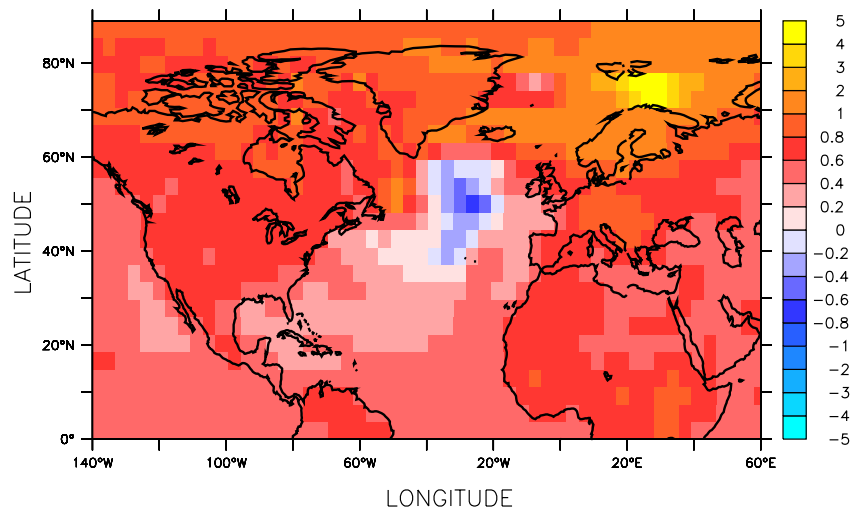

(b) SLP 50yr lag response (hPa), KCM

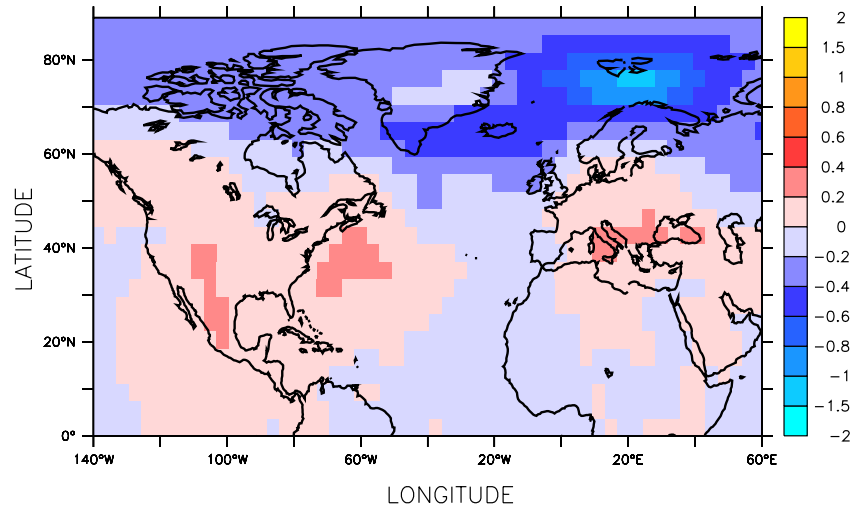

Figure 8: Composite (high minus low) of a) SAT $\left[{ }^{\circ} \mathrm{C}\right]$ and (b) SLP $[\mathrm{hPa}$ ] from the solar forcing experiment. The composites were computed using 100-year periods centred on the four maxima and minima in the solar forcing and introducing a lag of 50 years to account for the inertia.

mospheric mechanisms a second forced integration was performed, in which the dynamical ocean model was replaced by a fixed-depth $(50 \mathrm{~m})$ mixed layer model that by definition does not carry varying ocean dynamics. The response of NH-SAT is about $40 \%$ stronger in the mixed layer run in comparison to that simulated by KCM. We display the difference of centennial means around year 250 (solar maximum) and year 750 (solar minimum) from the mixed layer run. Again, a lag (20 years) was introduced to account for the inertia. The SAT response pattern (Fig. 9a) in the run without varying ocean dynamics is much more flat than that in the run with varying ocean dynamics. In particular, no cooling is simulated over the North Atlantic, which sharpens the point made above about the prominent role of the MOC in shaping the SAT response to solar forcing. A weak local minimum in the North Atlantic is simulated, which is due to the stronger westerly winds in that region in response to anomalously low pressure in the high latitudes and anomalously high pressure further to the south (Fig. $9 b)$. The strong cooling in the North Atlantic simulated in the solar experiment with KCM (Fig. 8a) can thus not be explained by a changed atmospheric circulation and (a) SAT 20yr lag response $\left({ }^{\circ} \mathrm{C}\right)$, MLO

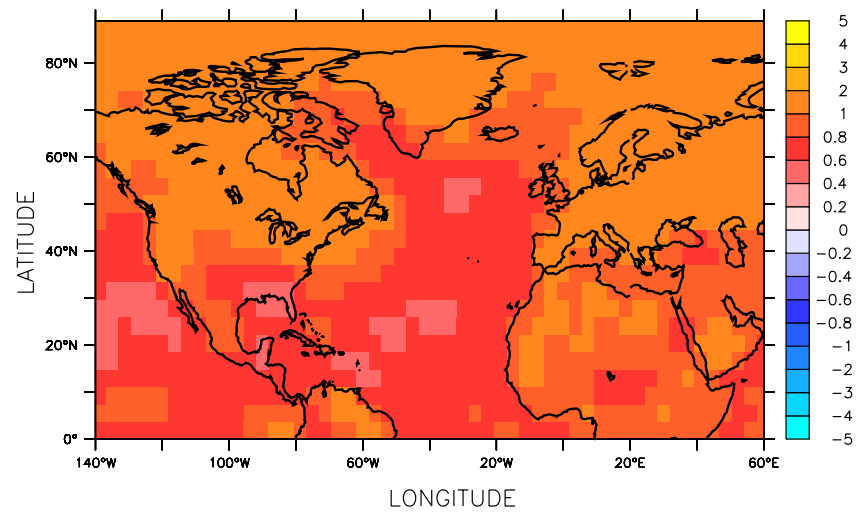

(b) SLP 20yr lag response ( $\mathrm{hPa}$ ), MLO

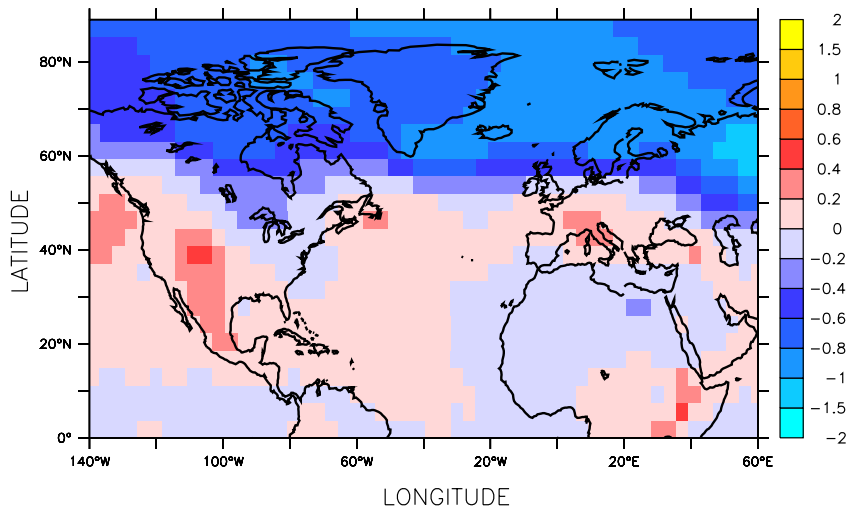

Figure 9: Composite (high minus low) of a) SAT $\left[{ }^{\circ} \mathrm{C}\right]$ and (b) SLP $[\mathrm{hPa}$ ] from the solar forcing experiment when the dynamical ocean model is replaced by a fixed-depth $(50 \mathrm{~m})$ mixed layer model without varying ocean dynamics. The composites were computed using 100-year periods centred on the maximum and minimum in the solar forcing and introducing a lag of 20 years. Only one cycle was computed.

the associated enhanced heat loss from the ocean to the atmosphere.

The high-low SAT composite in KCM shows strongest changes in the North Atlantic portion of the Arctic, specifically in the Barents Sea (Fig. 8a), although a weakened MOC would imply the opposite. Both observations and modeling studies indicate the existence of a positive dynamical feedback between sea ice, the atmospheric and the oceanic circulation in this region (IKEDA, 1990; ADLANDSVIK and LOENG, 1991; MYSAK and VENEGAS, 1998; BENGTSSON et al., 2004). Consider a situation in which the sea ice retreats initially in response to an enhanced solar forcing. This leads to the generation of anomalous cyclonic circulation in the lower atmosphere and thus to strengthened westerly winds over the western opening of the Barents Sea, thereby increasing both the oceanic and atmospheric heat transport into the region, which reinforces the initial change. The mechanism for the amplification of the response in the Barents Sea will be described in more detail and in the context of rapid climate transitions in a forthcoming paper (SEMENOV et al., in press). 
(a) SAT response to $\mathrm{CO}_{2}$

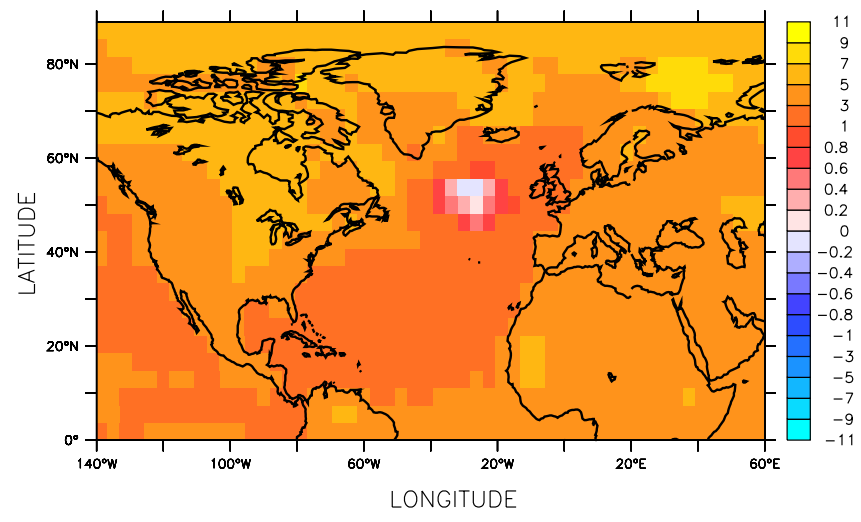

(b) SLP response to $\mathrm{CO}_{2}$

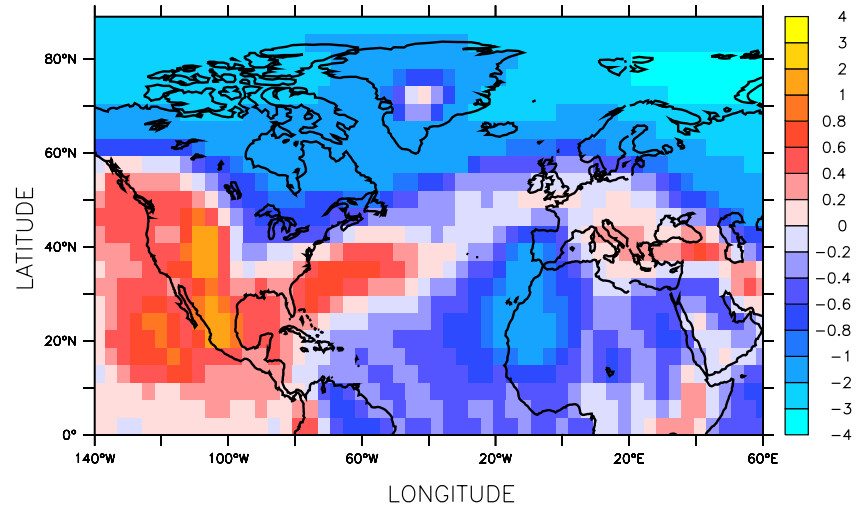

Figure 10: a) SAT $\left[{ }^{\circ} \mathrm{C}\right]$ and b) SLP $[\mathrm{hPa}]$ response in the ensemble of double $\mathrm{CO}_{2}(1 \% / \mathrm{yr})$ experiments. See text for details. Shown are the differences between the means of the last and first 30 years. The results were averaged over all 4 realisations.

It has been suggested (SHINDELL et al., 2001; LUTERBACHER et al., 2004) that the NAO is a main agent in shaping the response to solar forcing. We find only a small NAO-forced response in our experiment with periodically varying solar forcing (Fig. 8b). For instance, no statistically significant changes in the NAO-spectrum were found at the forcing frequency (not shown). It should be mentioned, however, that the SLP response pattern projects onto that of the Arctic Oscillation (AO). KCM simulates a strong sea level pressure (SLP) anomaly out-of-phase with the solar forcing over the Atlantic portion of the Arctic and over Scandinavia, with strongest changes of up to $1 \mathrm{hPa}$ over the Barents Sea (Fig. 8b), and considerably weaker in-phase changes further to the south. As described above, this type of sea level pressure response tends to amplify the solar-forced temperature change in this sector, specifically over the Barents Sea, most of Scandinavia, and Eastern Europe.

Additional experiments in which the $\mathrm{CO}_{2}$ concentration was increased by $1 \%$ year yield very similar spatial response patterns in SAT and SLP over the Northern Hemisphere (Fig. 10). We note, however, that the forcing amplitude in the solar experiment is much stronger than the changes observed during the $20^{\text {th }}$ century (e.g., HEGERL et al., 2007). Inferences about the role of so- lar forcing for the $20^{\text {th }}$ century warming can thus not be drawn from the sensitivity experiment presented here.

\section{Decadal predictability}

The results of the model simulations are of interest to decadal predictability. In principle both the internal and external variability can give rise to predictability. Two types of predictability are generally discussed: the predictability of the first and that of the second kind. The former results from changes in the initial conditions the latter from changes in the boundary conditions. Here we discuss the potential decadal predictability (BOER, 2004), i.e. the question of whether the decadal variability is strong enough to be clearly distinguished from the background climate noise. We investigated the potential predictability only in the control run. The ratio of the SAT variance in the band $10-100$ years relative to the total SAT variance was computed using annual mean values (Fig. 11a). The North Atlantic-Arctic Sector is clearly a region of high potential decadal predictability. Other regions of high potential decadal predictability are the North Pacific and the South Atlantic. Interestingly, the decadal predictability potential is concentrated in the mid- and high latitudes, while the interannual predictability potential is concentrated in the Tropics, specifically in the Equatorial Pacific (not shown).

Like in the North Atlantic the relatively high potential decadal predictability in the South Atlantic originates partly from the basin-wide decadal-scale MOC variability. The relationship between the decadal-scale MOC and North Atlantic SST variability is shown by means of a lag-correlation analysis (Fig. 11b). The MOC strength as defined as the maximum of the overturning streamfunction at $30^{\circ} \mathrm{N}$ was lag-correlated with the North Atlantic SST averaged over the latitude belt 40$60^{\circ} \mathrm{N}$, a region that is strongly influenced by the MOC (LATIF et al., 2004). The correlation is highly significant (above the $95 \%$ level) and the MOC strength leads the North Atlantic SST by several years, indicating the MOC drives the SST changes.

\section{Discussion}

A series of extended-range integrations were performed with the Kiel Climate Model (KCM) in order to study internal and external climate variability in the North Atlantic Sector. KCM simulates pronounced internal variability up to millennial timescales in the Northern Hemisphere surface air temperature (SAT) and the Meridional Overturning Circulation (MOC) in a multimillenial control integration. Multicentennial MOC variability is controlled by Southern Hemisphere and multidecadal variability by Northern Hemisphere processes. The centennial-scale variability shares many common aspects with that found in previous ocean model studies (e.g., Mikolajewicz and Meier-Reimer, 1990; PIERCE et al., 1995; DRIJFHOUT et al., 1996; OSBORN, 1997), while the decadal-scale variability is consistent with that simulated in other coupled models (e.g., DELWORTH and MANN, 2000; KNIGHT et al., 2005 and 
(a) Potential decadal predictability

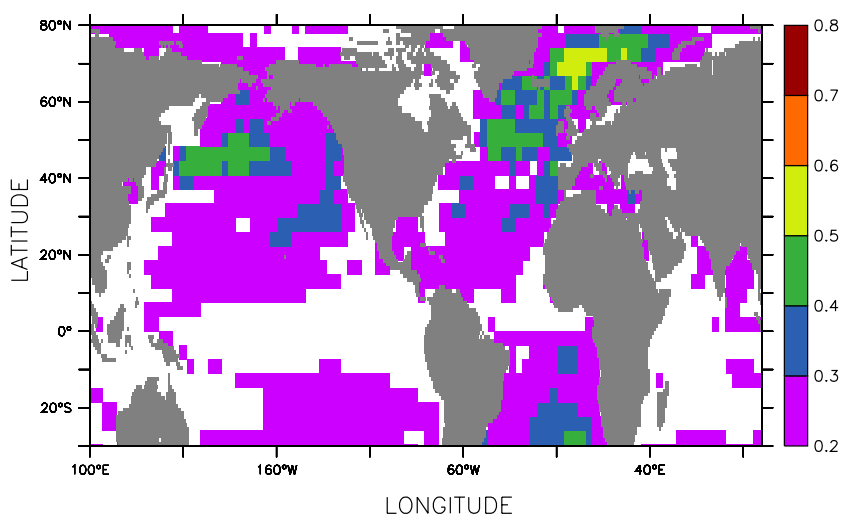

(b) Lag correlation: MOC vs. NA-SST

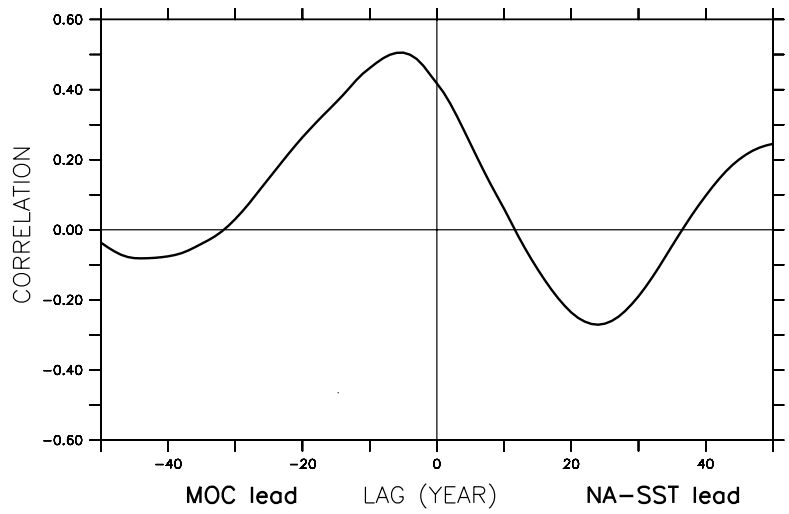

Figure 11: a) Potential predictability as defined by the ratio of SAT variance in the band $10-100$ years relative to the total variance computed from the control run. b) Lag-correlation between an index of MOC strength and a North Atlantic SST index. Annual data were used in both panels. Prior to the computation of the lag-correlation an 11-year running mean filter was applied.

2006). The millennial variability was not studied in detail given the relatively short integration time. We have also investigated the climate response to periodic millennial solar forcing. The simulated decadal to centennial Northern Hemisphere SAT variability in the run with time-varying solar forcing and the control run are both consistent with paleoclimatic reconstructions of the last two millennia, given the large uncertainty in these. The variability in the solar forcing experiment, however, is at the high end of the reconstructions. The changes in the MOC provide a strong negative feedback on Northern Hemisphere surface air temperature, overriding the direct effects of the local solar forcing over the North Atlantic. Solar brightening was observed during the early $20^{\text {th }}$ century. At that time, the North Atlantic warmed rapidly rather than cooled. This could suggest that internal processes may have played a more important role in driving the warming than the anomalous solar forcing.

The presence of natural climate variability, internally or externally driven, makes the early detection of an anthropogenic climate signal a challenge. The results presented here are important with respect to the detection of anthropogenic climate change in different ways. First, the presence of the strong internal variability may hinder early detection of anthropogenic climate change, as the variability patterns are not orthogonal to the climate changes patterns. SAT variability associated with the Atlantic Multidecadal Variability (AMV), for instance, does project onto the globally averaged SAT. Second, the surface response patterns associated with millennial solar forcing, a potentially important external natural driver of climate, and greenhouse gas forcing are also similar. Third, the observed Northern Hemisphere SAT exhibited rather strong multidecadal variability during the $20^{\text {th }}$ century. In the Arctic, for instance, the rate at which warming evolved during 1920-1940 was as strong as the warming rate observed during the most recent decades, an observation also seen in North Atlantic SST and European SAT (Fig. 1). Thus, the recent strong climate changes in the Arctic including the strong sea ice retreat may be caused by a superposition of anthropogenic and natural (internal) factors. Finally fourth, the AMV is oscillatory in nature in KCM and other climate models, and probably also in the real world (Fig. 1), which is supported by Northern Hemisphere SAT reconstructions of the last millennium. This provides a decadal predictability potential. Climate model projections for the next few decades could thus benefit from the initialization with present climate conditions. SMith et al. (2007) and KEENLYSIDE et al. (2008), for instance, show encouraging results with regard to decadal forecasting.

\section{Acknowledgments}

We would like to thank D. Dommenget and V. SEMENOV for many fruitful discussions. This work was supported by the Sonderforschungsbereich 754 (www.sfb754.de) of the German Research Foundation (DFG), the "Nordatlantik" project of BMBF, and the EU-projects Ensembles and Dynamite. The model integrations were performed at the Computing Centre at Kiel University and the DKRZ Hamburg. This paper is a contribution to the Excellence Cluster "The Future Ocean".

\section{References}

Adlandsvik, B., H. Loeng, 1991: A study of a climatic system in the Barents Sea. - Polar Res. 10, 45-49.

Bengtsson, L., V. A. Semenov, O. M. Johannessen, 2004: The early twentieth-century warming in the Arctic A possible mechanism. - J. Climate 17, 4045-4057.

BoER, G., 2004: Long-timescale potential predictability in an ensemble of coupled climate models. - Climate Dynam. 23, 29-44.

Bond, G., B. Kromer, J. BeEr, R. Muscheler, M.N. Evans, W. Showers, S. HofFMAnN, R. LOTTI-Bond, IRKA H., G. BONANI, 2001: Persistent Solar Influence on North Atlantic Climate. - Science 294, 2130-2136, DOI: 10.1126/science.1065680.

Crowley, T.J., 2000: Causes of climate change over the past 1000 years. - Science 289, 270-277.

CubAsch, U., R. Voss, 2000: The influence of total solar irradiance on climate. - Space Science Reviews 94, 185198. 
Delworth, T.L., M.E. MAnN, 2000: Observed simulated multidecadal variability in the Northern Hemisphere. Climate Dynam. 16, 661-676.

Delworth, T., S. MANABE, R.J. Stouffer, 1993: Interdecadal variations of the thermohaline circulation in a coupled ocean-atmosphere model. J. Climate 6, 1993-2011.

Drijfhout, S., C. Heinze, M. LATIF, E. MAIERREIMER, 1996: Mean circulation internal variability in an ocean primitive equation model. - J. Phys. Oceanogr. 26, 559-580.

Folland, C.K., T.N. PAlmer, D.E. PARKER, 1986: Sahel rainfall worldwide sea temperatures, 1901-85. - Nature 320, 602-607, DOI:10.1038/320602a0.

GANOPOLSKI, A.S. RAHMSTORF, 2001: Rapid changes of glacial climate simulated in a coupled climate model. Nature 409, 153-158, DOI:10.1038/35051500.

HASSELMANN, K., 1976: Stochastic climate models. Part I: theory, - Tellus 28, 473-485.

Hays, D., J. Imbrie, N.J. Shackleton, 1976: Variations in the Earth's Orbit: Pacemaker of the Ice Ages. - Science 194, 1121-1132.

HEGERL, G., et al., 2007: Understanding Attributing Climate Change. - In: Climate Change 2007: The Physical Science Basis. Contribution of Working Group I to the Fourth Assessment Report of the Intergovernmental Panel on Climate Change. - Cambridge University Press, Cambridge, United Kingdom New York, NY, USA.

IKEDA, M., 1990: Decadal oscillations of the air-ice-ocean system in the Northern Hemisphere. - Atmosphere-Ocean 28, 106-139.

JANSEN, E., et al., 2007: Palaeoclimate. - In: Climate Change 2007: The Physical Science Basis. Contribution of Working Group I to the Fourth Assessment Report of the Intergovernmental Panel on Climate Change. - Cambridge University Press, Cambridge, United Kingdom New York, NY, USA.

Jones, P.D., M.E. MANN, 2004: Climate over past millennia. - Rev. Geophys. 42, RG2002, DOI:10.1029/2003RG000143.

Keenlyside, K., M. Latif, J. Jungclaus, L. KornBLUEH, E. ROECKNER, 2008: Advancing decadal-scale climate prediction in the North Atlantic sector. - Nature 453, 84-88, DOI:10.1038/nature06921.

KNight, J.R., R.J. Allan, C.K. Folland, M. VElLINGA, M.E. MANN, 2005: A signature of persistent natural thermohaline circulation cycles in observed climate. - Geophys. Res. Lett. 32, L20708, Doi:10.1029/2005GL024233.

Knight, J.R., C.K. Folland, A.A. SCAIFE, 2006: Climate impacts of the Atlantic Multidecadal Oscillation. - Geophys. Res. Lett. 33, L17706, DOI:10.1029/2006GL026242.

LAtif, M., E. Roeckner, M. Botzet, M. Esch, H. HAAK, S. HAGEMANN, J. JungClaus, S. LegutKe, S. MARSLAND, U. MIKOLAJEWICZ, 2004: Reconstructing, monitoring, predicting multidecadal-scale changes in the North Atlantic thermohaline circulation with sea surface temperature. - J. Climate 17, 1605-1614.

LAtif, M., C. BÖNING, J. Willebrand, A. Biastoch, J. DengG, N. KeEnlyside, G. MAdeC, U. SchwecKENDIEK, 2006: Is the Thermohaline Circulation Changing? - J. Climate 19, 4631-4637.

LATIF, M., C.W. BÖNING, J. Willebrand, A. BiASTOCH, F. Alvarez, N. Keenlyside, H. Pohlmann, 2007: Decadal to Multidecadal Variability of the Atlantic MOC: Mechanisms Predictability. - In: Ocean Circulation: Mechanisms Impacts - Past Future Changes of Meridional
Overturning, A. Schmittner, J.C.H. Chiang, S.R. HEMMING (Eds.), AGU Monograph 173 149-166.

Luterbacher, J., D. Dietrich, E. Xoplaki, M. GrosJEAN, H. WANNER, 2004: European Seasonal Annual Temperature Variability, Trends, Extremes Since 1500. Science 303, 1499-1503, DOI: 10.1126/science.1093877.

MADEC, G., 2008: NEMO reference manual, ocean dynamics component: NEMO-OPA. Preliminary version. - Note du Pole de modélisation, Institut Pierre-Simon Laplace, IPSL: France, No. 27, 1288-1619.

Mikolajewicz, U. E. MAIER-Reimer, 1990: Internal secular variability in an ocean general circulation model. - Climate Dynam. 4, 145-156.

Muscheler, R., J. BEER, 2006: Solar forced Dansgaard/Oeschger events? - Geophys. Res. Lett. 33, L20706, DOI:10.1029/2006GL026779.

MysaK, L.A., S.A. VEnEGAS, 1998: Decadal climate oscillations in the Arctic: A new feedback loop for atmosphere-ice-ocean interactions. - Geophys. Res. Lett. 25, 3607-3610.

OSBORN, T.J., 1997: Thermohaline oscillation in the LSG OGCM: Propagating anomalies sensitivity to parameterizations. - J. Phys. Oceanogr. 27, 2233-2255.

PARK, W., M. LATIF, 2008: Multidecadal Multicentennial Variability of the Meridional Overturning Circulation. - Geophys. Res. Lett. 35, L22703, DOI:10.1029/2008GL035779.

Park, W., N. Keenlyside, M. Latif, A. Stroeh, R. REDler, E. RoECKNER, G. MADEC, 2009: Tropical Pacific Climate its Response to Global Warming in the Kiel Climate Model. - J. Climate 22, 71-92.

Pierce, D. W., T. P. BARnETT, U. Mikolajewicz, 1995: Competing roles of heat freshwater flux in forcing thermohaline oscillations. - J. Phys. Oceanogr. 25, 2046-2064.

ROECKNER, E., G. B̈̈UML, L. BONAVENTURA, R. Brokopf, M. EsCH, M. GiorgetTA, S. Hagemann, I. Kirchner, L. Kornblueh, E. MANZINI, A. Rhodin, U. Schlese, U. SCHUlzWEIDA,A. TOMPKINS, 2003: The atmospheric general circulation model ECHAM5. Part I: Model description. - Max Planck Institute for Meteorology Rep. 349, 127 pp.

Schmittner A., M. LATIF, B. Schneider, 2005: Model projections of the North Atlantic thermohaline circulation for the 21st century assessed by observations. - Geophys. Res. Lett. 32, L23710, DOI:10.1029/2005GL024368.

SEMENOV, V.A., W. PARK, M. LATIF, in press: Barents Sea inflow shutdown: A new mechanism for rapid climate changes. - Geophys. Res. Lett., DOI:10.1029/2009GL038911.

Shindell, D.T., G.A. Schmidt, M.E. MAnN, D. Rind, A. WAPLE, 2001: Solar forcing of regional climate change during the Maunder Minimum. - Science 294, 2149-2152, DOI:10.1126/science.1064363.

Smith, D.M., S. Cusack, A.W. Colman, C.K. FolLAND, G.R. HARRIS, J.M. MURPHY, 2007: Improved surface temperature prediction for the coming decade from a global climate model. - Science 317, 796-799.

Timmermann, A., M. LATIF, R. Voss, A. GRÖtZnER, 1998: Northern hemispheric interdecadal variability: A coupled air-sea mode. - J. Climate 11, 1906-1931.

VALCKE, S., 2006: OASIS3 user guide. - PRISM technical report No. 3, 64 pp., available on http://www.prism.enes.org

ZHANG R., T.L. DELWORTH, 2006: Impact of Atlantic multidecadal oscillations on India/Sahel rainfall Atlantic hurricanes. - Geophys. Res. Lett. 33, L17712, DOI:10.1029/2006GL026267. 